\title{
Fair Trade and Justice: A Case Study of Fair Trade and its Effect on the Freedom of Bolivia's Indigenous Women
}

Tamara Stenn

\begin{abstract}
Amartya Sen has written that for justice to be realized, freedom needs to be expanded. Fair Trade, a model of global trade that puts into motion billions of dollars, purports to promote justice, and therefore expands freedom. Fair Trade is a four-pillar structure comprised of institutions, producers, consumers, and government/policy. An economic, ethnographic study of Bolivia's indigenous women working within the Fair Trade model for the past 15 years reported mixed results. The women questioned the justice of the model based on negative experiences induced by irregular work, stress, and unsupportive communities. At the same time, women acknowledged enhanced capabilities and opportunities emanating from skills development, empowerment, and income. Although it increased women's freedom, there are ways in which Fair Trade could be made fairer through transparency, reciprocity, and public reasoning. This work is significant in the sense that it creates a new understanding of justice and trade that enables women's voices to be heard.
\end{abstract}




\section{Keywords}

economic justice, empowerment, ethics, Fair Trade, globalization,

quality of life, social capital, women

\section{Resumen}

Amartya Sen ha planteado que para lograr justicia, se necesita expandir la libertad. El Comercio Justo, un modelo de comercio global que pone en movimiento miles de millones de dólares, pretende promover la justicia y, por consiguiente, expandir la libertad. El Comercio Justo es una estructura de cuatro pilares que comprende instituciones, productores, consumidores y gobiernos/políticas gubernamentales. Un estudio económico y etnográfico de mujeres indígenas de Bolivia que han trabajado con este modelo de comercio los últimos 15 años reportó resultados muy diversos. Las mujeres cuestionaban la justicia de un modelo basado en experiencias negativas resultado del trabajo irregular, del estrés y de la falta de apoyo por parte de las comunidades. Al mismo tiempo, las mujeres reconocían mejoras en las capacidades y oportunidades que emanaban del desarrollo de habilidades, el empoderamiento y los ingresos. Aunque incrementó la libertad de las mujeres, hay maneras por las cuales el Comercio Justo podría llegar a ser más justo a través de transparencia, reciprocidad y razonamiento público. Este trabajo es importante en la medida que crea una nueva interpretación de la justicia y del comercio que permite escuchar la voz de las mujeres.

\section{Palabras claves}

calidad de vida, capital social, Comercio Justo, empoderamiento, ética, globalización, justicia económica, mujeres

This paper examines Fair Trade and its effect on indigenous women producers of export clothing within the context of justice as theorized by Amartya Sen. Sen's theory of justice revolves around three arguments: justice needs to be broadly understood - encompassing conflicting ideas and experiences; expanding capabilities and opportunities bring greater freedom and more justice; and public reasoning and democracy smooth out justice's inconsistencies enabling it to be more fully realized.

Fair Trade is a multi-billion dollar industry started in the 1960s by church groups and religious leaders as a way to help impoverished congregants in less developed countries. Fair Trade evolved from the field, having been developed by people who had deep ties to and knowledge of the 
impoverished people amongst whom they worked. It is a bridge that helps to connect producers to markets in a socially, culturally, and environmentally respectful way. Fair Trade is held up by four pillars: institutions; producers; consumers; and governments/policy. US and European Fair Trade institutions such as the World Fair Trade Organization (WFTO), Fairtrade International (FLO), and Fair Trade Federation set the rules and impetus for Fair Trade to take place. Fair Trade producers create goods in accordance with Fair Trade institutional guidelines. Consumers purchase these goods, hoping to make a difference in a producers' life and because of the quality and uniqueness of the products. Governments support the environment in which this trade is experienced, indirectly, through trade agreements and policy. Bolivia's Fair Trade was developed when aid workers and foreign entrepreneurs who knew about Fair Trade from their home countries introduced the concept to producer groups with whom they worked and helped them to gain membership into the different institutions. However, $60 \%$ of the Bolivian Fair Trade women in this study were not directly affiliated with a Fair Trade institution because of challenges in gaining access to the program and a lack of need to have an "official" Fair Trade affiliation. Challenges to access included complicated online forms or the lack of having an office in the US. Most importantly, product sold on the merits of its being well made. Even products from groups with official Fair Trade recognition were not always retailed as Fair Trade; rather they were sold as high quality handmade goods. All groups followed Fair Trade guidelines regardless of their formal affiliation. Though begun with good intentions, Fair Trade was developed without input from the producers or consumers it served. This lack of discussion and democratic process eroded some of the fairness that Fair Trade was capable of providing.

Indigenous women's own understanding of Fair Trade was captured through field research and ethnographic study. The author's 15 years of experience working with indigenous women who were also Fair Trade knitters in Bolivia brought a deep knowledge of the people and their customs. Research found that Fair Trade increased justice for women producers to a degree. Women reported positive economic outcomes in the form of new opportunities. They also experienced growth in self-esteem and leadership skills, and pride in new skills learned in the form of increased capabilities. Fair Trade women were challenged by inconsistent orders, stress from deadlines coupled with family responsibilities, and physical ailments from working long hours at home under poor working conditions. Understanding Fair Trade in relation to Sen's ideas of justice generated a bittersweet recognition of the current state of Fair Trade. Viewing Fair Trade as development illuminated 
the same gender and altruism challenges that are present in many Gender and Development (GAD) programs. In addition, recent migration brought challenges that were consistent with migrants worldwide. Engagement in public discussion with space allotted for participation in democratic decision making is essential in realizing a more just and fair system of trade, especially in these times of change.

\section{Case Study - Fair Trade Bolivian Knitters}

In Bolivia there were six large, well-established, export-quality alpaca hand knitting organizations, associations, non-profits, and businesses. All but one had roots in women's micro and small enterprise development projects (MSE) popular in Bolivia in the 1980s and 1990s. And all have long term access to a specific foreign market through the ongoing support of a closely affiliated foreign buyer or contact. Fair Trade knitting was a cottage industry, where members took materials home to knit and meet weekly for technical assistance, to receive new orders, materials, and socialize with each other. The six groups studied here were La Imillia, La Kantuta, ARSEBOLSM (Artisans of Bolivia, Señor de Mayo), Alma de los Andes, ASAP, and Artesania Sorata. They are located in Bolivia's highlands and high valleys. Each of these six groups had been participating in the global economy for over 15 years. Though only two were recognized members of the International Federation of Alternative Trade (IFAT - the Latin American arm of the World Fair Trade Organization, WFTO) and one was a member of the USA based Fair Trade Federation, all adhered to the same principles of Fair Trade as developed by IFAT. These principles included fair wages and financing, protection of the environment and local culture, and long term commitment to working together in a respectful manner. Together, these organizations employed upwards of 1,000 people, mostly uneducated farm women, giving them the pride and dignity of a skilled career, extra income, and a flexible work schedule. Gross annual sales generated by these cottage industry organizations were estimated at over $\$ 300,000$ (Stenn 2010).

I met with a total of 66 hand knitters in May 2010, attending weekly meetings and participating in home stays with both my Bolivian family, who does not knit, and other knitters. I often discussed findings with my Bolivian family to get their interpretation on what was being said and experienced. My family consisted of merchants, teachers, and college graduates who made up Bolivia's growing middle class. They lived in simple housing near El Alto's new urbanizaciones (urban developments) on the outskirts of the city of La Paz, 
maintained their family lands in the countryside, spoke Quechua and/or Aymara, and wore western style clothing. These informal discussions helped to create a solid meaning around Bolivia's recent political change, new laws and trends.

\section{Sen and Justice}

Amartya Sen defines freedom as one's ability to build hers or his capabilities and realize opportunities in an open, ever changing, participatory environment. Freedom he asserts, leads to justice. Justice he feels is a dynamic concept that is supported by open discussion, transparency, and participation. Justice is a highly democratic, non-hierarchal, and inclusive process. Fair Trade is understood to be a more just manner of global trade, or "justice" trade. By understanding the concept and experience of Fair Trade in relation to Sen's ideas of justice, one can better comprehend how Fair Trade grows freedom and justice, for those who have it the least.

Measuring freedom, what one achieves rather than what one owns, enables the quality of one's life to be understood. Fair Trade was designed to improve producers' quality of life by expanding their achievement. Though Fair Trade did increase producer resources, bringing more income and development to communities, the achievement it brought people in the form of empowerment, self-determination, and organizational skills, proved significant. Sen associates freedom with opportunity and capabilities. In order for Fair Traders to experience more freedom and a better quality of life, they need to be able to expand their opportunities and capabilities. Opportunities, explaines Sen, are the ability to pursue objectives, such as a crime free life, or Fair Trade sales. Capabilities are the tools and abilities one possesses, such as self-defense skills, or production skills. Opportunities and capabilities together lead to greater freedom. For example, access to Fair Trade sales, opportunities, expanded capabilities, and the ability to create fine products, results in Fair Trade producers achieving a higher level of freedom. They have income and confidence in their ability to organize and create valued goods. The process within which Fair Trade producers pursue freedom was significant. Rather than measuring utility or resources, Sen recommends the freedom-based capability approach. (Sen 2009, 231).

In the freedom based capability approach, Sen explains, an individual's advantage is judged by the person's "capability to do things he or she has reason to value" $(2009,231)$. A Fair Trade producer's advantage would be measured by how much opportunity they have to achieve the things they value, and the freedom they have to engage in this opportunity. Fair Trade 
knitting, as this study will show, did not always produce freedom, as defined by Sen. Fair Trade is dependent on producers, institutions, consumers, and governments and operates in fluctuating global markets within different local societies. Though Fair Trade did improve producers' quality of life in many ways, the degree of freedom one experienced varied due to Fair Trade's different dependencies. Choice is important in this model. A Fair Trade producer's choice to engage in Fair Trade capabilities is impacted by gender and society. Though one's participation in a Fair Trade project is feasible, one might not be able to choose to join because of outside pressures. A lack of choice leads to a lack of capabilities being realized, and freedom being lost.

Building capabilities is not enough though. There needs to be an outlet or market for these capabilities. Sen makes an important distinction between doing something and being free to do that thing. For example in the developing world, education is available to both young boys and girls. However, due to poverty, many girls were forced to work at home rather than go to school. The girls were not free to pursue an education, though the opportunity existed. The capability that one had (i.e., access to education) must reflect the opportunity and choice that it brought (i.e., pursing the education). Producers experience a lack of opportunity when Fair Trade projects exist in their countries because - due to time, cultural, or gender restraints, they are unable to participate in them.

Public reasoning, the ability of issues of contention to be discussed in an open arena, is key to understanding justice (Sen 2009). Public reasoning enables ideas to be shared, different views and sides to be revealed, new perspectives to be heard, and creates a place for discussion, debate, and, in time, understanding. Participatory governments, such as democracies, are rooted in public reasoning.

A comprehensive understanding of democracy encompasses political participation, dialogue, and public interaction. Public reasoning is the medium in which democracy's participation, dialogue and interaction take place. This medium of public reasoning is what, according to Sen, links democracy to justice (and ultimately freedom).

Democracy is not just limited to a single state government. As Sen has stated, "the demands for open impartiality make the global perspective a necessity for a full consideration of justice anywhere in the contemporary world" $(2009,328)$. Open impartiality, the ability to view multiple sides of an issue without them being considered conflictive, but rather simply different, is achieved through public reasoning. Open impartiality and public reasoning 
are not easy to engage in on the global scale as we live in a multicultural, multinational world of stark differences, interests and needs. Nevertheless, as a world society we have made progress over the millennia to engage others democratically, in government by discussion.

In Fair Trade, public reasoning can be found in the transparency of the model. Public reasoning is present in the ability of consumers and producers to communicate with each other, of product origins and producers to be known, of price structures to be clearly disclosed, and for producers having a representative role and voice in Fair Trade institutions.

Public reasoning is vastly important in the realization of justice. Whether supported by governments, constitutions, or through individual initiative, the ability for people to openly engage in meaningful discussion, hear different points of view, maintain an open mind, accept differences as being different and not merely right or wrong, are all imperative for the preservation of personal freedom, the earth and justice. Through open discussion, inclusion and a focus on creating space to grow achievement, greater justice can be achieved.

\section{Migration and Lifestyle}

Over the past five years, the highlands of Bolivia have experienced an economic shift from a barter/subsistence economy where farmers grew their own food and traded or sold surplus in local markets, to a wage based economy. This has been caused by higher world market prices for minerals resulting in increased mineral production and export, and climate changes such as drought and extreme weather patterns that have negatively affected agricultural production leading to a rise in food costs. These factors together have created a recent increase in movement of rural families to the cities. This rural migration has led to the development of a variety of new "squatter communities" or urbanizaciones on the outskirts of large cities such as La Paz.

It has been expensive to live in the urbanizaciones. Food and fuel were no longer available from the farm and have needed to be purchased. Markets and jobs are not within walking distance so bus fares have needed to be paid. Children have been exposed to new consumer goods such as toys and candy in which they have wanted to participate. Many newly migrated women have sought to join the informal economy seeking work as house cleaners, nannies, clothes washers, gardeners, or street venders of homemade foods. Some have been invited by neighbors to join producer groups and have received 
training in artisanal production. The Fair Trade knitters studied in this paper have chosen this route.

Most urbanization dwellers have been hybrid migrants. They have lived in the cities during the week and have return to the countryside on weekends and holidays to cultivate their family lands producing potatoes, quinoa, and wheat. The women speak their indigenous languages of Quechua or Aymara depending on their region, dressed in the indigenous chola style of long full skirts, shawls, and bowler hats, and associate more with the countryside than city life, though most have had cell phones and have been comfortable navigating city terrain. Their children have been westernized in their dress, speak Spanish, play in internet cafes, and attend suburban public schools. Husbands have been mixed. Some men have been present and supportive of the women and their new wage work. Others have been absent; they have been working elsewhere, though local family members have had influence on the actions of the women left alone to care for their children and homes.

The development of Fair Trade style knitting groups can be traced back to the MSE development programs for women, popular in the 1980s. Women were trained as project leaders and taught a production skill. As they taught others that skill, they created products to sell. ARSEBOLSM was developed and run by a Bolivian woman, Antonia Rodriguez, who saw knitting as a way to empower women. Her son, Carlos, described the business as a social movement rather than an economic enterprise because of its strong focus on empowerment. A foreign tourist took an interest in their work and eventually opened markets for them in Europe, introduced them to Fair Trade, and through private enterprise, supported the organization's long term growth and development. This was a common route to the global market for many Fair Trade artisan producers, including the ones I personally worked with as a Fair Trade business owner myself. Rodriguez, like other knitting group leaders, often traveled abroad with the support of the WFTO and other NGOs to show her products, share her experiences, and promote Fair Trade to consumer audiences. Foreign volunteers were an important presence at ARSEBOLSM and many of the other knitting groups, with student and professional interns providing assistance with design, organization, infrastructure, and communication. Bridge building between producers and consumers through internships and speaking tours was an important aspect of Fair Trade. It enabled participants to better understand each other in the context of their culture, lifestyle, and as individuals. Fair Trade and 
development agencies facilitated the bridge building between producers and consumers.

Knitting groups competed in the free market on the basis of the quality of their knitting, designs and prices. Their work had to appeal to the export consumer with little hint of their ethnic origin or Andean cultural traditions. Many products were not even marketed as Fair Trade items by wholesale buyers, but instead retailed as hand crafted garments. There was some "ethnic branding" in the Andean symbols used on garment labels and some designs featured prominent Andean motifs such as intis (suns) and llamas. Their target market, European and US consumers, was broad and allowed a sizeable number of knitters to be employed, though it also demanded that knitters be "closely attuned to the changing needs of often far-away markets" (Eversole 2006, 953). The Fair Trade knitters' western-style designs were a practical response to market demand.

\section{Women Speak}

Data for this paper was gathered through ethnographic methods using participatory rural appraisal (PRA), the Talking Stick and thick description. This enabled women's voices to be captured without the influence of survey questions or researcher bias. The data collection occurred during women's regular weekly knitting meetings, where work was handed in, new orders given out, and instruction provided. It was common for guests to attend meetings. Some were foreign or local volunteers who arrived to teach new skills or designs, students doing research, health workers, social workers, lawyers, or educators. Anthropologists were not looked upon fondly since they had a reputation of taking information from the women and not sharing the results. Knitting leaders chose to present me as an economics professor and longtime Fair Trade buyer. Leaders chose to introduce me as a buyer not to encourage the women to sell me product, but to establish that I had an understanding of their world.

Meetings were a social and educational time for the women. Though regionally based, some women traveled for more than an hour to get to their meeting location. Most were within walking distance or 15 minutes distance by public transportation. Because it was time for the potato harvest (for the highland meetings) and Mother's Day (for the meetings in the valleys), there was only a $60 \%$ attendance in most meetings. Mother's Day in Bolivia was celebrated throughout the week with schoolchildren inviting their mothers to their schools for special ceremonies, gifts, food, thanks and recognition. 
The majority of knitters in this study were mothers aged 25-45 with an average of five children each and a husband who was present in the home about $40 \%$ to $60 \%$ of the time. One knitter was in college and found the flexible knitting schedule fit well with her studies. Three others were single young adults, daughters of knitters, who were working to save money for their own futures. About $20 \%$ were elderly and widowed or retired, enjoying knitting for its socialization and as a source of financial security.

The findings of this study were consistent amongst the different group studies and appeared to be indicative of the realities of most knitters' experiences with Fair Trade. Though I had been working with the knitting groups for 15 years, I did not interact individually with the knitters themselves and had never asked them about their experiences before. Rather I worked directly with the knitting leaders and let them communicate with the knitters in their own way. Based on my knowledge of Andean culture and living, I expected the outcome of this study to be different from the outcomes of other Fair Trade producer studies that focused on male land owners such as coffee farmers, using surveys and measureable outcomes. I was interested in capturing a woman's voice while she described her own situation as she understood it. I did not create categories or labels, but instead collected words with the Talking Stick and worked with the women to draw out similarities in themes and experiences. The Talking Stick, a Native American tool, gave each person a turn to speak about a topic without any interruption, question, or judgment, allowing words to be spoken and heard in a neutral, supportive, environment.

The spoken words were grouped by the women into themes. I gathered these themes and placed them into the following categories: Economics, Self, Family, Education, Social, Fair Trade, and Health. True to the Andean way of balancing experiences, there is a positive and a negative presented for most categories. The Andean tradition is based on balance and cycles. Opposites complete the whole. For example, male and female together are a whole just as negative and positive make up a whole. Using the TAMS analyzer computer program to create quantitative data from qualitative research, I was able to preserve the words spoken by knitters while also giving them a numerical value. The positive and negative effects of Fair Trade as reported by the knitters can be seen in fig. 1 below and will be individually examined in the following sections of this paper. 


\section{The Effect of Fair Trade on Indigenous Women Knitters}

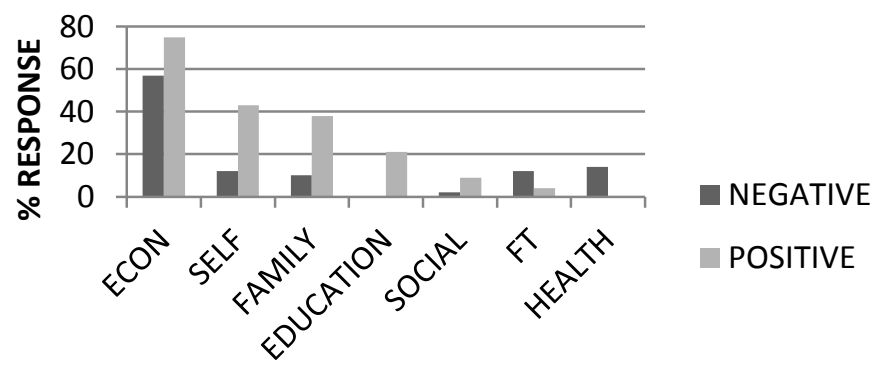

THEME CATEGORIES

Figure 1: Coded TAMS Analysis of Talking Stick data

Stenn 2010

\section{Economic Effects}

There was an $18 \%$ annual attrition rate in knitting groups as different opportunities arose for women, others found the work too complicated or not worth the time, though many knitters made a career of knitting, staying with their groups for ten or more years. The main benefit that knitters spoke of was the opportunity to earn extra income with flexible, home based work. Unlike Fair Trade comodities such as coffee, handicrafts had no price floor or minimums set for Fair Trade. Pricing was market driven depending heavily on the cost of alpaca yarn. When I first began knitting in 1996, alpaca sold at \$18 US a kilo. Within 15 years, it had climbed to $\$ 32$ a kilo. A small, high quality, handknit, woman's alpaca sweater from Bolivia would typically cost \$53 to make. The costs were figured in the following way: \$24 for yarn, \$5 for administrative costs, $\$ 24$ for the knitters (Fig. 2). This same sweater would retail for more than $\$ 120$ after moving through a relatively short supply chain. $\$ 53$ was an in-country cost of production. The sweater was then shipped to the foreign Fair Trade wholesaler who placed the original order. With marketing, staff, administrative, and capital costs, a 50\% mark-up of the original good was not unusual. The resulting wholesale price of this sweater would now be $\$ 60$. Retailers also had their own costs and made use of an 
industry system called "keystone," where clothing bought wholesale was marked up $100 \%$ for retail, resulting in the sweater being sold for $\$ 120$ in a Fair Trade shop. Often consumers and knitters asked how this was fair. In Bolivia the average wholesale to retail markup was $30 \%$ instead of in the US at $100 \%$, so items cost less, though people also earned less (Stenn 2010).

\section{Cost to Knit a Small Fair Trade Sweater}

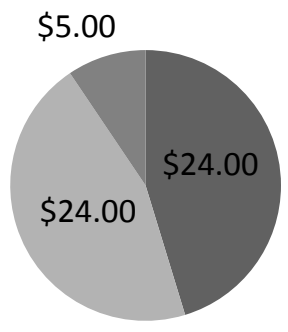

Alpaca Yarn

Knitting (labor)

Fees (organization)

Figure 2: Costs to knit a KUSIKUY sweater

Sorce. KUSIKUY Clothing Co., LLC, 2011. Adapted with permission

It took the average knitter about 20 hours, over the course of five days, to knit an adult sweater. This was a $\$ 1.20$ per hour pay rate. The official Bolivian minumum wage climbed $11 \%$ from $\$ 82$ a month to $\$ 92$ a month (647 Bolivianos) in 2009 (Hudson \& Hanratty 1989; Rajnes 2010). Bolivian men have a 40-hour work week though the legal work week for women is five hours less to give them time for cooking and home chores. Bolivian women earning minimum wage, working 35 hours a week, make \$0.66 an hour, almost half of what a Fair Trade knitter earned. Though well paying, Fair Trade knitting was not steady work. Sweaters were a seasonal item and orders were not received year round. The average Fair Trade knitter earned about $\$ 350$ a year total (Stenn 2010). About 20\% of the knitters spoke of other work they also did such as gardening, machine knitting, hat making, and dressmaking, noting that while they sometimes were paid more in these jobs 
than they made from knitting, these jobs were hard to find and they offered "less opportunities" (Stenn 2010). Some knitters said they were just knitting for the moment and would leave as soon as better work was available.

To give knitters' earnings a context, Bolivia had a per capita GDP of $\$ 4,800$ a year which equaled $\$ 400$ a month per person. Thirty percent of the Bolivian population lived below the international poverty line of less than $\$ 2$ per day. Rural farm families in Bolivia lived on an average of \$100 a month (CIA, World Factbook). The recent migrants in this study lived on an average of $\$ 200$ a month per family in El Alto and other urban developments.

The knitters' $\$ 350$ in earnings, made over the winter and fall months of June to November, helped to supplement family earnings. Knitting earnings were spent on improving the quality of food for children, buying school supplies, and also helping with larger household expenses such as paying for a sewer hook-up or digging a well. The negative economic aspects of Fair Trade were linked to the irregularities in available work and the seasonal nature of the industry. When the women used to farm full time knitting was good work because orders arrived in the winter when there were no crops to tend. Now that knitters had left their farms and were in the cities, year-round work was needed.

To understand the economic benefits Fair Trade from a justice perspective, we can look towards Sen's capabilities approach. When women were able to engage in the work they felt was meaningful, such as Fair Trade knitting, their capabilities increased. When the work women produced was valued by others, resulting in more sales, they expanded their opportunities. By engaging both economic capabilities and opportunities, women realized more freedom and experienced greater economic justice. However, Fair Trade was more than just an economic model.

\section{Effects on Self Development}

There were many personal development benefits that women associated with their knitting experiences. Knitting group leaders took great pride in the self-development and leadership opportunities they brought to the knitters, through guest speakers and outside programs. Many found the knitting itself to be personally enjoyable. Knitters also learned new skills that helped them in all areas of their life. "I have to organize my time," explained one participant from the Ninth of January Group, who was learning how to better manage her home life. There was also a feeling of pride and accomplishment when completed work was handed in. 
There were personal challenges knitters faced as they tried to manage their paid knitting work and their unpaid home responsibilities. Bolivian life was full. Mornings started around 5:00 a.m. and were spent cleaning and cooking while afternoons were spent taking care of children. School for the children was half a day, Monday through Saturday. Evenings were spent with the family and husbands, who arrived home from work around 8:00 p.m. Dinner was at 9:00 p.m. Most knitters went to sleep around 11:00 p.m., if they were not on deadline with a knitting order. In between this schedule, there were family obligations, weddings, baptisms, funerals, farming, visits, holidays and other events. Families were large and extended families regularly interacted and lived nearby, so family time was significant in the Bolivian lifestyle. Time and lifestyle challenges affected the knitters as they tried to build paid work into their busy schedule. A knitter from Las Nieves asked, "Also, at what moment will we have time to knit?" (Stenn 2010).

The knitters' need to balance their double workload of paid and unpaid labor was a challenge not just for them, but for many women worldwide, especially those in the Global South. Researchers found that as more women entered into the wage economy, their housework responsibilities did not change (Brickell \& Chant 2010). New wage labor was a growing part of women's "ever-expanding portfolio of maternal obligations" (Chant 2002, 467). Household responsibilities overwhelmingly fell on women. A United Nations Development Programme (UNDP) study of nine developing and 13 developed economies found that unpaid productive labor accounted for twothirds of women's work, compared with only one-quarter to one-third of men's and that women worked more hours than men overall (Rodenberg 2004, 17, Box 5).

Time management was one of the first things new knitters were taught. Knitters learned to measure and structure their time and to delegate responsibilities. By learning how to plan jobs, and train others to do them, they created more time for their paid work, and had a well-functioning household. The children, now living in the urban developments and relieved of their previous farm chores, often took on cooking, cleaning, and child care tasks. A knitter from the January Ninth group explained "While we are knitting we can get up early, cook in the morning and in the afternoon, wash and knit. The children are always helping with the knitting." The work the children were doing in this case was not the knitting itself, which was highly skilled, but it was caring for their younger siblings, cleaning, and cooking. The husbands sometimes helped with the knitting production too, mostly by 
making and attaching pompoms on designs, sewing buttons, or other finishing details. Young boys reported enjoying their new responsibilities knowing that someday they would be fathers and could use these skills. Tasks were assigned based on age and ability, rather than gender. Time management and other self-development training were organized by the women knitting leaders themselves, based on their own experiences, as a way to empower the women and ensure orders were completed well and on time.

Nevertheless, the time demands on knitter's labor were not easy and not all households participated in these new time management programs. Studies of Latin America showed there was a strong, often church supported, conservative belief that women's entry into wage labor resulted in social ills. It was believed that children left unattended, while the women worked, became delinquent as homes were not properly cared for. Working women were viewed as selfish individuals seeking their own fulfillment through paid work (Molyneux 2003). This was not the case in Bolivia, where Andean views of cooperation are highly valued and families strove to work together. Children were often brought to work. Knitting work was done in the home, allowing the women to be with their children while also earning an income. The real importance of being with the children and family was heard in this statement made by a January Ninth knitter, "We knit in our houses, we do not leave or sell, abandoning our children. But this work lets us stay in the house and attend to our children."

Researchers found that women often had no alternative other than to take on the double load of paid labor and household responsibilities. Often women needed to compensate for men's lack of household participation or contribution, known as a "feminization of responsibility and obligation" (Chant 468). This was the case in Bolivia too, as the men no longer farmed full time and needed to seek labor for themselves as well. A woman entering into the workforce was often necessary. Bolivian women, however, embraced, "feminization of responsibility and obligation," and were reluctant to participate in the shared or reduced housework model that many feminist theories promoted. They felt that in their Andean way of being, men and women complimented each other and worked together to make a whole. It did not mean that they had to do equal tasks, but that by completing their own tasks, they could meet their collective needs. Sen's 'cooperative conflict' model required abandoning the notion that households were "intrinsically cohesive, internally undifferentiated entities, governed by 'natural' proclivities to benevolence, consensus and joint welfare maximization" (1987, 5). Time management training helped women to better organize their days without having to radically re-design their households.

Bolivian Studies Journal / Revista de Estudios Bolivianos

http://bsj.pitt.edu Vol. 20 • 2014 • doi: 10.5195/bsj.2014.100 • ISSN 1074-2247 (print) • ISSN 2156-5163 (online) 


\section{Effects on Family}

Although Fair Trade created important income for families, it brought challenges too. Knitters had to share their family time with knitting work. Sometimes they overslept after knitting all night causing their children to be late for school, or they were busy knitting on a deadline and missed a school presentation, or were late picking up their children from school. Time for knitting created conflict as women were torn away from working to support their children and being physically present.

While women were more inclined to have their household work together with their knitting, husbands were not always supportive of their wives' extra work. They felt the children and household should come first and did not like their wives taking on extra work that they saw as negatively impacting family life. "We have fights with our husbands," admitted a knitter from Las Nieves. While Fair Trade supported gender equity, knitting was a woman-focused activity in which men were not present. Researchers found gender based economic opportunities, such as those in Fair Trade knitting, often generated tensions between men and women at household and community levels. These tensions could be rooted "around the implications of women's increased autonomy and presence in the public sphere, men's resentment at being displaced as providers, or their envy of what they see as women's privileged access to project resources" (Molyneux 2007:256).

The stress and power shifts experienced with migration also impacted families. Research found that in general, women were more likely to emphasize the advantages associated with migration, while men consistently stressed their loss of status (Mcllwaine 2008). The resulting transformations in gender ideologies and power relations led in some cases to gender-based violence, as men "struggled to cope with women's new-found independence and used violence to assert their power and ensure the maintenance of hegemonic masculinities" (Mcllwaine 2008, 5). In addition, when fathers or husbands were marginal to the workings of a gender based program, it resulted in them being marginalized from the care of children (Molyneux 2007). "Antipoverty policies," explained Molyneux, "cannot disadvantage another vulnerable group in the process (men)" (IBID 145). Support from households was necessary for Fair Trade knitting to be a successful option for women. Unequal access to opportunities caused tension and strife. Perhaps the gender focus of Fair Trade knitting needed to be expanded. 
The benefits felt by families far outweighed the challenges of unsupportive households. While $12 \%$ of participants did feel some negative personal effects from Fair Trade, largely due to lack of time and family cooperation, $43 \%$ reported positive personal effects. These positive effects were the ability to help the family with extra earned income, pride in their work and the ability to have family help with supporting the knitting work. As argued by Kearns Murphy, "The task of poverty eradication is to eradicate the structures that create and depend upon poverty itself, rather than fix the people who are vulnerable to poverty. The people are transitory, the place is permanent ... if we are to confront the effects of poverty we must confront wealth and its privilege" $(2001,32)$; this not only involved taking into account gender relations but addressing the models that guide the direction of economic development. Fair Trade's position amongst families during times of change makes it an important tool for building gender inclusion and development.

\section{Effects on Education}

Numerous Fair Trade studies showed that the principal, economically unmeasured, and largely invisible benefit of Fair Trade was the training it provided to producers. This was evident in my studies as well. Ten percent of participants specifically cited education and training as being a helpful effect of Fair Trade while none crtiticized the training received. In addition, $20 \%$ of participants cited positive personal development incorporated through new skills learned. Fair Trade education positively effects one's personal development. Learning to knit high quality export product brought a tremendous amount of pride and satisfaction to the knitters. Many felt they learned to knit better, were able to work with exact measurements and produce at higher quality. "I am an artisan, I am a professional," a knitter from Grupo UMA said with pride. Many knitters reported pride in being a professional, in creating product for export, and being a self sufficient producer with independent earnings. Education included learning about quality control, design details, and technical aspects of knitting such as sizing. Strong relationships formed between knitting leaders who were also technical teachers and knitters. Knitting leaders also felt a commitment to educating members.

In development programs, interventions to reduce women's poverty included investing in women's capabilities through education, health, and vocational training and enhancing their access to assets such as employment, credit and housing (Molyneux 2007). However, projects which assumed 
that women were free and available for unpaid work failed because they overloaded exhausted women without offering them adequate remuneration, any support in the form of childcare, or any training in practical skills needed to obtain a paid job (Molyneux 2007). It was found that the most effective way of tackling poverty amongst women was for them to enter into paid labor (Molyneux 2007). The educational element of Fair Trade knitting functioned because it took place during the women's scheduled knitting meetings. While participating in education programs, women were also knitting, consulting with leaders on designs, dropping off work, getting new orders, measuring out yarn, and socializing. Often a snack was served and child care provided. The women looked forward to coming to meetings because they were able work and earn income while also learning new skills and ideas.

\section{Social Effects}

The social effects of Fair Trade have rarely been studied though are clearly significant, especially in the areas of human rights and justice. Sen noted the importance of people being able to meet and share information in order for social transformation and justice to take place. Fair Trade, with its weekly meetings and leaders inspired by human rights and self development, provided an important place for this to happen.

"Women bring social problems to the group where they are seen, acted on," explained Rodriguez. Many knitters spoke of the joy of being in a group with other women. They noted that there was no "egoism" within the women's groups and that their "work is shared, we help each other," as a member of Grupo Mercedes B explained. Knitters felt that they received compassion and support from the other women in their groups. "Knitting together, we forget our sadness and worries," elaborated a Grupo Nieves knitter. There was enjoyment in getting to know other women, outside of their family and community, and also "foreigners, volunteers, clients and cholitas," a January Ninth group member elaborated. "We laugh and eat a lot" explained a woman at the Alma de los Andes meeting, referring to the tea and bread that is served at every meeting. They also enjoyed marching together in local parades celebrating workers and civic groups.

On the other hand, knitters spoke of the sporadic and unpredictable nature of the orders and the lack of job security they felt. Knitters reported that they lost social time within their communities. They were busy all of the time and could no longer visit with neighbors. Even worse, when a neighbor 
visited, the knitter felt uneasy because the visitor was "taking away" from knitting time. Many knitters spoke of the challenges of interruptions from neighbors, children and family, and not having a specific place to work.

Research supported these sentiments. Studies showed that though women were often income-poor, what was most important is their role on the front lines of dealing with poverty. Globally, the burden of household survival has fallen on women, with the burden increasing as they have taken on paid labor (Chant 2008). Meanwhile men's labor contributions have fallen. Chant observed, "The social worth of women's efforts tends to go unacknowledged, robbing them of personal gains, prestige or satisfaction" (2008, 190).

\section{Fair Trade as an Effect}

Many Fair Trade studies, including this one, have shown a lack of understanding of Fair Trade by participants, both on the consumer and producer side. Often conditions of exploited workers and environmental degradation, found in conventional trade, are hidden, so the definition of Fair Trade as a system of trade that protects the environment, workers and culture often seems weak or insignificant. South Americans working to develop Fair Trade legislation in their own countries criticized world Fair Trade guidelines as not being specific enough or strong enough to really support full fairness in trade. The aspects of the Fair Trade model that were most criticized were those of transparency and reciprocity. Fair Trade producers were required to demonstrate their production and pay accounts to buyers, but buyers were not required to provide the same transparency in their sales, markups, expenses and earnings. In addition, Fair Trade buyers were not required to follow any Fair Trade guidelines themselves. To the producers, this felt like hypocrisy since they were held to such guidelines. There was no direct communication between the producer and the consumer. The consumer could only hope that adequate earnings were passed on to producers. This created feelings of suspicion and exploitation amongst producers.

Fair Trade was developed without participants being given an active role in the design, management and evaluation of the program. Sen emphasizes the importance of public reasoning and democracy in order to build justice. He explains that through open discourse and debate, with participation from all sides, greater understanding and justice could be built (Sen 2009). The non-democratic nature of Fair Trade, developed with good 
intentions but without participant input, threatens its ability to truly bring forth justice.

\section{Health Effects}

Negative health effects were reported by knitters in all groups. Although only $14 \%$ of the knitters initially spoke of knitting's health effects, most knitters reported such negative effects in subsequent conversations. The health issues initially mentioned by knitters were largely due to the cottage industry structure of the knitting groups, which was not conducive to focused, detailed work. Knitting was often done for long hours at night in cold, low light conditions, with poor ergonomics. Night-time temperatures often dropped to below freezing causing indoor temperatures to fall to 50 degrees. There was no heat. Most knitters kept their knitting supplies in an aguayo (woven indigenous cloth used for carrying infants or objects) blanket or a woven plastic shopping bag tucked into a corner. Houses did not have much furniture so knitting was done seated on the floor. Knitters complained of sore fingers and shoulders, rheumatism and arthritis, from sitting and knitting for so many hours. They also complained of sore eyes, blurry vision and seeing "black dots" after knitting for long periods of time. Their lungs and eyes were compromised, many explained, by the dust and fibers that came off of the yarn. In addition, large orders with firm deadlines produced stress which was culturally difficult for knitters to manage. For Bolivians living in a culture where everything was expected to happen, "if god was willing" and "little by little," the idea of doing more than was possible was a foreign concept. However, most knitters agreed that knitting at home was one of the best parts of the job. Without being able to knit at home, where they could also care for the children and household, many would not be able to knit at all.

Upon learning of the health concerns of the knitters, I purchased simple face-masks and held workshops in ergonomics including stretching, repetitive motion injury and eye strain prevention. Knitters found the exercises easy to follow and felt the face masks, affordable and locally available, worked well. I changed our production schedule to offer year-round production and am asking customers to place orders earlier in order to give knitters a fuller season schedule. These were easy changes for a Fair Trade buyer to make and greatly affected the women's wellbeing. Engaging Sen's ideas of democracy and pubic reasoning created a space where knitters could share their experiences and challenges. Once these were known, they were 
easy to address. This example highlighted the importance of building democracy and public reasoning in the Fair Trade model, and giving producers, consumers and institutions a chance for all to listen and work together in the pursuit of even fairer trade.

\section{Conclusion}

Although it increased women's freedom, there are ways in which Fair Trade could be made fairer through more gender inclusion, transparency, reciprocity, and public reasoning. Understanding the economic effects of fair trade from a justice perspective enabled one to observe that when women were able to choose to work, orders were available, and they had time and family support to engage in these activities, they realized their full capabilities and also fully engaged in opportunity. They could knit as they wished and receive earnings, recognition, and support from the group. They realized both economic gains and social well-being. Their families' benefitted, and greater freedom and ultimately justice was experienced by the women.

Weekly meetings that enabled women to knit and earn while they learned were key in developing production and organizational skills that expanded capabilities and built self-confidence. Also key was the ability of women to knit at home and care for their children while also earning income. Earnings made the work worthwhile, though the sporadic nature of orders and the seasonality of the work, which was good in the past, were no longer enough for women's altered lifestyles today as migration has created new stressors and challenges. The lack of space for men in the knitting model isolated the women and caused strife in gender relations. The lack of space for all Fair Trade participants to engage in public reasoning and discussion prevented new ideas from emerging that could lead to fairer forms of trade emerging. Nevertheless, Fair Trade has built important bridges between consumers and producers through education and exchange.

A deeper understanding of the effects of Fair Trade on indigenous women can help to create a more just and equitable Fair Trade institutional model that includes local governance, producers and consumers, and that has transparent and fair methods of reciprocity and social reasoning. This new model could be used as an example for the expansion of Fair Trade into other market sectors influencing government policy, trade regulation and mutually beneficial agreements. 


\section{Works Cited}

BRICKELL, Katherine \& Sylvia Chant. 2010. "The Unbearable Heaviness of Being: Reflections on Female Altruism in Cambodia, Philippines, The Gambia and Costa Rica." Progress in Development Studies 10 (2): 145-59.

CHANT, Sylvia. 2008. "The 'Feminization of Poverty' and the 'Feminization' of Anti-Poverty Programmes: Room for Revision?" Journal of Development Studies 44 (2): 165-197.

---. 2007. Gender, Generation and Poverty: Exploring the 'Feminization of Poverty' in Africa, Asia and Latin America. Cheltenham, UK: Edward Elgar Publishing.

---. 2006. "Dangerous Equations? How Female-Headed Households Became the Poorest of the Poor: Causes, Consequences and Cautions." Feminisms in Development: Contradictions, Contestations and Challenges. Andrea Cornwall, Elizabeth Harrison and Ann Whitehead, eds. London: Zed Books. 34-47.

CIA. 2010. World Factbook. [https://www.cia.gov/library/publications/the-worldfactbook/geos/bl.html] downloaded May 24, 2010.

EVERSOLE, Robyn. 2010. "Empowering Institutions: Indigenous Lessons and Policy Perils." Society for International Development 53 (1): 77-82.

---. 2006. "Crafting Development in Bolivia." Journal of International Development 18: $945-955$.

HUDSON, Rex and Dennis Michael Hanratty. 1989. "Bolivia: A country study." Environmental Institute, Working Paper 07-02: 22-30.

MCLLWAINE, Cathy. 2008. "Negotiating Gender-Based Violence: The Paradoxes of Migration for Latin American Women in London." Department of Geography, Queen Mary, University of London.

MOLYNEUX, Maxine. 2007. "Two Cheers for CCTs." IDS Bulletin (38) 3: 69-74.

---. 2006. "Mothers at the Service of the New Poverty Agenda: PROGRESA/Oportunidades, Mexico's Conditional Transfer Programme." Journal of Social Policy and Administration 40 (4): 425-49.

---. 2002. "Gender and the Silences of Social Capital: Lessons from Latin America." Development and Change 33 (2): 167-188.

---. 2001. Women's Movements in International Perspective: Latin America and Beyond. New York: Palgrave Macmillan. 
---. 1998. "Analysing Women's Movements." Development and Change 29 (2): 219-245.

RAJNES, David. 2010. International Update: The Americas, Bolivia. [http://www.socialsecurity.gov/policy/docs/progdesc/intl_update/201012/index.html\#bolivia] downloaded December 12, 2010.

RODENBERG, Birte. 2004. "Gender and Poverty Reduction: New Conceptual Approaches in International Development Cooperation." Bonn: German Development Institute.

SEN, Amartya. 2009. The idea of Justice. Cambridge, US: The Belknap Press of Harvard University Press.

---. $\quad$ 1987. "Gender and Cooperative Conflicts." Wider Working Papers Series.

STENN, Tamara. 2010. Bolivia research field study. La Paz and Cochabamba, Bolivia. Various interviews with members of CAPROCA, Señor de Mayo, La Imillia, Alma de los Andes, Grupo Uma, Kantuta, Cooperación Belga de Desarrollo, $\mathrm{CECl}$, ComArt, RED OEPAIC, CIOEC, Ministerio de Desarrollo del Pueblo. May-July.

\section{$(\mathrm{cc}) \mathrm{BY}$}

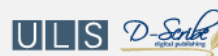

New articles in this journal are licensed under a Creative Commons Attribution 4.0 United States License.

This journal is published by the University Library System of the University of Pittsburgh as part of its D-Scribe Digital Publishing Program, and is cosponsored by the University of Pittsburgh Press. 